\title{
Sobre flores e canhões: canções de protesto em festivais de música popular
}

\author{
Vanda Lima Bellard Freire (UFRJ, Rio de Janeiro, RJ) \\ vandafreire@yahoo.com.br
}

Erika Soares Augusto (UFRJ, Rio de Janeiro, RJ)

erikasoaug@yahoo.com.br

\begin{abstract}
Resumo: 0 presente artigo aborda algumas canções de protesto apresentadas nos Festivais da Música Popular realizados no período 1965-1969, buscando compreendê-las em sua inserção no momento social e político em que surgiram e se fizeram ouvir. Foram realizadas análises de vídeos e áudio das apresentações das canções escolhidas, segundo a visão da História Cultural, baseada em aportes teórico-metodológicos da fenomenologia e da dialética. Desse modo, foram privilegiadas a escuta e as observações das autoras frente às gravações da época. Os festivais de música popular brasileira foram realizados durante a ditadura militar no Brasil, na década de 60 do século XX, abrigando, entre outras, manifestações das chamadas canções de protesto, da autoria de compositores como Chico Buarque, Geraldo Vandré, Caetano Veloso, Paulinho da Viola, entre outros. As conclusões apontam algumas convergências entre as características das canções analisadas, revelando também que elas atuaram veladamente como instrumento político de contestação.
\end{abstract}

Palavras-chave: festivais de música popular brasileira; canções de protesto; história da cultura; fenomenologia da música; Música Popular Brasileira.

\section{About flowers and cannons: protest songs in popular music festivals}

Abstract: The present article discusses some protest songs performed at the "Popular Music Festivals" held between 1965-1969 aiming to understand their role in the social and political context of that era. Based in a phenomenological and dialectic approach, analysis of videos and audio from performances of the selected songs were made, in a Cultural History perspective. Thus, the authors' reception of the recordings of that period was privileged. The Brazilian popular music festivals were held during the military dictatorship in Brazil in the 1960s, housing, among others, manifestations of the so called protest songs, written by composers like Chico Buarque, Geraldo Vandré, Caetano Veloso, Paulinho da Viola, among others. We can conclude that there are some convergences between the characteristics of the analyzed songs and also that they functioned as a means of questioning the political situation in a veiled way.

Keywords: Brazilian popular music festivals; protest songs; cultural history; Phenomenology of music; Brazilian popular music.

\section{1 - Introdução}

Este artigo tem origem em uma pesquisa de Mestrado (AUGUSTO, 2009), enriquecida posteriormente pelas autoras. 0 objetivo da pesquisa inicial foi o de buscar compreender algumas canções de protesto presentes nos festivais de música popular brasileira (MPB) da década de 1960, em sua inserção na sociedade, a partir da análise de exemplos escolhidos como estudos de caso. As reflexões foram construídas com base nos fundamentos da História da Cultura (BURKE, 2005), valorizando a inserção das canções no ambiente social e político da época.
VILARINO (1999) é um dos autores que procura conceituar a sigla MPB, embora reconhecendo as dificuldades dessa empreitada, em virtude das "várias camadas de significados que the foram incorporadas com o tempo" (VILARINO, 1999, p.18). Esse fato, segundo ele, impõe a necessidade de historicizar a expressão música popular brasileira, já que "qualquer música consumida e/ou produzida pelas camadas populares e em nosso idioma se encaixa em tal conceito" (p.18). Reconhecendo, portanto, que o conceito de MPB não é unânime, citamos VILARINO a seguir (p.18-19): 
A sigla MPB representa um movimento dentro da música brasileira, e sua trajetória de sucesso se inicia num momento em que uma nova ditadura se instaurava a partir do golpe de 31 de março de 1964 e em que recrudescia o conflito militar e ideológico em torno da Guerra do Vietnã. [...] Várias foram as definições para a MPB: música de protesto, música dos festivais, música politicamente engajada, Moderna Música Popular Brasileira, ou MMPB [...] Em termos geográficos, a MPB situa-se no eixo Rio - São Paulo, pólo de urbanização e modernização do país. Era um movimento musical urbano com um público em sua maioria de classe média e universitário. [...] (VILARINO, 1999, p.18-19)

Assim como o conceito de MPB, o de "canção de protesto" não goza de unanimidade. A Enciclopédia da Música Brasileira (1998, p.144) define canção de protesto como:

Gênero de canção de origem universitária, com que, a partir de 1965, os jovens compositores da classe média do Rio de Janeiro - RJ e de São Paulo - SP aspiravam dar consciência às grandes camadas da população dos problemas político-econômicos do Brasil. (Enciclopédia da Música Brasileira, 1998, p.144)

Revisando a literatura da área, surgem outras definições sobre esse gênero de canção, ressaltando seu enfoque político, como a que se segue:

Embora a canção de protesto seja frequentemente definida como um gênero de canção universitária surgido em 1964 e desaparecido com o Al-5, desde o início do século, e mesmo antes, canta-se criticamente a realidade social brasileira. Porém, diferente da crítica social e de costumes que caracteriza parte da produção musical dos anos 30, a partir da década de 60 e sobretudo após o golpe de Estado, o protesto passa a ser uma tendência ideológica na música popular - associado à luta contra a ditadura militar -, aparecendo como prática de agitação política e resistência ao autoritarismo. (COUTINHO, 2002, p.69)

A partir do reconhecimento do teor político e do diálogo crítico entre "texto e contexto" desenvolvido pelos compositores em canções das décadas de 1950 a 1970, NAVES (2010) utiliza o conceito de "canção crítica" para referir-se a elas.

\section{Segundo a autora a canção crítica surgiu}

no final dos anos 50 e ao longo dos anos 60, época em que a canção popular tornou-se o lócus por excelência dos debates estéticos e culturais, suplantando o teatro, o cinema e as artes plásticas, que constituiam, até então, o foro privilegiado dessas discussões. (NAVES, 2010, p.19)

CÉSAR (2007) utiliza a categoria "canções de resistência" para esse mesmo universo de canções que, diante do momento da ditadura, através de artifícios poéticos na construção de suas letras, buscaram veicular mensagens políticas.

Quer utilizemos, portanto, o conceito de canção de protesto, quer utilizemos o conceito de canção crítica ou de resistência, estaremos nos referindo ao mesmo fenômeno político que NAVES (2010), COUTINHO (2002) e CÉSAR (2007) procuram caracterizar no âmbito da canção brasileira, em meados do século XX. Diferentes autores, revisitados, destacam diferentes aspectos relativos a essas canções, mas o reconhecimento de seu engajamento político é, em geral, recorrente.
Quanto ao conceito de canção, também não consensual, podemos citar como exemplo a definição do Dicionário Grove de Música (1994, p.160-161), que a descreve como "peça musical, habitualmente curta e independente, para voz ou vozes, acompanhada ou sem acompanhamento, sacra ou secular. Em alguns usos modernos, o termo implica música secular para uma voz".

De qualquer forma, o reconhecimento da canção como gênero musical que envolve voz cantada, geralmente acompanhada por instrumento, é mais ou menos geral. 0 reconhecimento, contudo, das canções apontadas como canções de protesto nem sempre é unânime. $A$ Banda, de Chico Buarque, é uma das que mais suscitam divergências sobre seu possivel teor político ou de protesto, mas concordamos com Carlos Drummond de Andrade, que, em artigo publicado pelo Jornal do Brasil, em 14/10/1966, enfatiza esse caráter.

Drummond inicia o artigo, tocante depoimento da época, destacando a necessidade de "ver a banda passar", como forma de superar a desesperança que o momento político provocava. Ele destaca ainda a singeleza de $A$ Banda, canção "tão brasileira e tão antiga", características essas necessárias, ainda segundo ele, diante da carência geral de amor:

0 jeito, no momento, é ver a banda passar, cantando coisas de amor. Pois de amor andamos todos precisados, em dose tal que nos alegre, [...] nos dê paciência e esperança, força, capacidade de entender, perdoar, ir para a frente. Amor [...] que nos vacine contra o feio, o errado, o triste, o mau, o absurdo e o mais que estamos vivendo ou presenciando. A ordem, meus manos e desconhecidos meus, é abrir a janela [...], é subir ao terraço como fez o velho que era fraco, mas subiu assim mesmo, é correr à rua no rastro da meninada, e ver e ouvir a banda que passa. [...] A felicidade geral com que foi recebida essa banda tão simples, tão brasileira e tão antiga na sua tradição lírica, [...] dá bem a ideia de como andávamos precisando de amor. (ANDRADE, 1966)

Na continuidade do artigo, Drummond faz alusões sutis à ditadura militar ("pois a banda não vem entoando marchas militares, dobrados de guerra") e alude também aos partidos políticos do momento, assumindo como seu partido "o desejo, a vontade de compreender pelo amor e de amar pela compreensão". Os comentários de Drummond sinalizam, sem dúvida, A Banda como uma canção de protesto (ou pelo menos de conteúdo político), ainda que sutil:

Pois a banda não vem entoando marchas militares, dobrados de guerra. Não convida a matar o inimigo, [...] nem a festejar com uma pirâmide de camélias e discursos as conquistas da violência. Esta banda é de amor [...]. Meu partido está tomado. Não da ARENA nem do MDB, sou desse partido congregacional e superior às classificações de emergência [...]. Ele não obedece a cálculos da conveniência momentânea, não admite cassações nem acomodações para evitá-las, e principalmente não é um partido, mas o desejo, a vontade de compreender pelo amor, e de amar pela compreensão. Se uma banda sozinha [...] provoca até o aparecimento da lua cheia no céu confuso e soturno, crivado de signos ameaçadores, é porque há uma beleza generosa e solidária na banda, há uma indicação clara para todos os que têm responsabilidade de mandar e os que são mandados [...]. $\mathrm{E}$ se o que era doce acabou, depois que a banda passou, que venha outra banda, Chico, e que nunca uma banda como essa deixe de musicalizar a alma da gente. (ANDRADE, 1966) 
Divergências à parte, as canções críticas, de resistência ou de protesto, no momento focalizado neste artigo, são reconhecidas por muitos autores como presença importante nos festivais de música popular brasileira. Esses festivais tiveram lugar em um momento de grande conflito político, em virtude da ditadura militar instaurada pelo golpe militar de 31 de março de 1964, estendendo-se até a redemocratização do país, em 1985. 0 plano político foi marcado pelo autoritarismo, anulação dos direitos constitucionais, perseguições, prisões, torturas e censura aos meios de comunicação. Vários instrumentos de repressão foram utilizados pelo governo militar para tentar neutralizar as oposições ao regime, desencadeando a censura aos meios de comunicação e às manifestações artísticas, principalmente a partir de 1969. As prisões e torturas foram frequentes, levando os cidadãos a viverem em clima de insegurança.

Diversos segmentos da sociedade procuraram reagir à ditadura, como alguns elementos ligados à Igreja Católica, advogados, artistas e estudantes. Os artistas reagiram de várias formas, em geral buscando aliar 0 seu protesto à manifestação artística. Alguns exemplos dessas manifestações são as iniciativas do Centro Popular de Cultura (CPC) e da União Nacional dos Estudantes (UNE), bem como a realização dos festivais de música popular brasileira do final dos anos 60, que alcançaram muita repercussão e revelaram diversos compositores e intérpretes, ainda que paire sobre esses festivais a dúvida de que eram momentos de aparente liberdade, concedidos pelo próprio governo militar ("desafio consentido pelo governo militar", segundo CESAR, 2007, p.100).

Outras manifestações importantes, visando a utilizar o espaço cênico como oportunidades de conscientização política, podem ser identificadas nos trabalhos de Cacá Diegues e Glauber Rocha, no cinema. No teatro, podem ser citados, nessa mesma linha, os grupos "Oficina" e "Arena".

Após o Ato Institucional $n^{\circ}$ 5, decretado em 13 de dezembro de 1968, a repressão às manifestações artísticas se intensificou. Seus participantes, muitas vezes, foram exilados, como é o caso de Chico Buarque de Holanda, Caetano Veloso, Gilberto Gil e Geraldo Vandré, algumas vezes por decisão própria.

Em meio a essa turbulência política, os festivais surgiram e deram abrigo às canções reconhecidas por muitos autores como canções de protesto. As críticas ao regime militar, mesmo quando não explícitas, motivavam a reação das autoridades, desencadeando maior repressão e endurecimento. No que tange às letras das canções, elas eram submetidas à censura da Polícia Federal que, depois de analisá-las, indicava o que deveria ser modificado, podendo liberá-las ou não para apresentação pública.

Como parte do forte engajamento ideológico que envolvia os participantes dos festivais, tanto intérpretes como compositores defendiam a música "autêntica" e de temática social e nacional, paralelamente a outras "bandeiras" ideológicas, buscando reafirmar nossas raizes culturais através da utilização de gêneros brasileiros como o samba ou a moda de viola. Esse desejo de afirmação nacional ou de brasilidade perpassa frequentemente a produção musical apresentada nos festivais e é reconhecido por vários autores. NAVES (2010, p.40-41), comentando o surgimento da ideia de MPB, na década de 60 , observa que os músicos que a criaram:

Procuraram conciliar a veia experimental de compositores e intérpretes como Tom Jobim e João Gilberto com as informações políticas e culturais de um momento marcado pela busca de igualitarismo social, de liberdade política e pelo sentimento de brasilidade. [...] Não se tratava de uma proposta de regionalismo, mas da criação de uma linguagem que expressasse o Brasil. (NAVES, 2010, p.40-41)

Nesse cenário permeado de ideologias contraditórias situam-se os Festivais, objeto da pesquisa que deu origem a este artigo. 0 período selecionado (1965-1969) é reconhecido por vários autores como aquele em que a "Era dos Festivais" atingiu o auge, mas também aquele no qual teve início seu declínio: "O ano de 1968, que foi o ano com mais festivais, que foi o da fadiga dos festivais, da Tropicália, do Al-5, não foi um ano qualquer. Em 1968 a Era dos Festivais entrava na curva descendente da parábola" (MELLO, 2003, p.334).

No decorrer da pesquisa e após seu término, muitos autores foram revisados (FAVARETTO, 2000; MELLO, 2003; VILARINO, 2006; CÉSAR, 2007; entre outros), propiciando diferentes interpretações sobre vários aspectos relativos às canções de protesto e à década seguinte, em que 0 movimento conhecido como Tropicália trouxe novos rumos para a canção brasileira, pois, segundo Caetano Veloso, os tropicalistas procuraram virar tudo pelo avesso (Jornal do Brasil, 10/08/1985). 0 tropicalismo questionava, até mesmo, a ideologia nacionalista e teve a irreverência como uma forte característica.

De acordo com os autores consultados, há justificativas para o fim da "Era dos Festivais", como o esgotamento do modelo e também o gradativo esvaziamento causado pela intervenção dos militares no conteúdo das canções, gerando desencanto de muitos compositores, o que levou diversos deles a deixarem o país.

As canções que foram selecionadas para análise situamse entre aquelas que são reconhecidas pela literatura (ou parte dela) como canções de protesto e que obtiveram um dos primeiros lugares nos Festivais em que foram apresentadas, alcançando, portanto, maior penetração. Foram escolhidas, com esses critérios, quatro canções, sendo uma de cada ano do período selecionado - $A$ Banda (Chico Buarque) - 1966, Roda Viva (Chico Buarque) - 1967, Pra não dizer que não falei de flores (Geraldo Vandré) - 1968 e Sinal Fechado (Paulinho da Viola) 1969. Do ano de 1965 não foi escolhida canção para ser analisada por não ter sido apontada pelos autores consultados nenhuma que configurasse caráter de 
protesto. A escolha dos exemplos para análise não teve pretensão de generalização das conclusões, pois buscou, apenas, com esses estudos de caso, construir pontos de reflexão que permitissem aprofundar a compreensão sobre as canções e sua inserção política e social. Através da literatura, foram também revisadas análises de outras canções, servindo de contraponto às reflexões construídas, ampliando-as.

Consideramos que as "canções de protesto" concretizaram um discurso no qual o questionamento da realidade nacional não só é legítimo, como "engajado" e transformador, procurando ultrapassar a função de entretenimento para alçar a de instrumento de conscientização política e, se possivel, de tomada de poder e de transformação social.

Acreditamos que a pesquisa originária tenha contribuido com algumas novas visões sobre a canção brasileira de protesto lançadas nos festivais, permitindo tecer algumas reflexões sobre a inserção da música na trama social e política em que se situa. Também acreditamos que os enriquecimentos posteriores à pesquisa inicial tenham ampliado essa contribuição.

\section{2 - 0 olhar voltado sobre as canções}

0 olhar teórico-metodológico dedicado às canções de protesto, no plano mais amplo, baseou-se em fundamentos da História da Cultura (BURKE, 2005). As canções de protesto foram visualizadas como fenômenos inseridos na trama social da época, com o entendimento de que as manifestações musicais se movem entre diferentes espaços, em um processo de circularidade cultural (GINZBURG, 1987), transformando-se e configurando novos significados, em atualização permanente (FREIRE, 1994).

A percepção dos movimentos circulares que envolveram as canções foi importante, pois permitiu visualizar as apropriações, trocas e reelaborações diversas empreendidas pelos compositores das canções, articulando, nelas, diferentes tempos e espaços, diferentes visões de mundo. Buscou-se, assim, construir um relato histórico não restrito ao ponto de vista oficial, mas abrigando diferentes pontos de vista, segundo uma "história vista de baixo", que não desconsidera, contudo, as estruturas sociais mais amplas em que os fenômenos, inevitavelmente, se inserem:

\footnotetext{
[...] A história das "pessoas comuns", mesmo quando estão envolvidos aspectos explicitamente políticos de sua experiência passada, não pode ser dissociada das considerações mais amplas da estrutura social e do poder social. Esta conclusão, por sua vez, leva ao problema de como a história vista de baixo deve ser ajustada a concepções mais amplas da história. (BURKE, 1992, p.54)
}

Essa visão nos pareceu oportuna, pois os festivais da década de 1960, apesar de serem idealizados por individuos de segmentos sociais de melhor poder aquisitivo, representavam tentativas de diálogo com outros segmentos da população, buscando construir uma contracorrente ao regime que vigorava na época, ou seja, contra o poder ditatorial instituído. Além disso, trouxeram para aquele momento gêneros musicais antigos revisitados e memórias diversas de nossa cultura.

As contradições sociais inerentes à sociedade da época puderam ser valorizadas com aportes da dialética, aportes esses presentes em diferentes nuances nos autores que fundamentaram teoricamente a pesquisa. As visões da dialética e da fenomenologia aplicadas à pesquisa estão articuladas neste trabalho como possibilidades metodológicas subjetivistas, capazes de propiciar novos entendimentos e interpretações (FREIRE; CAVAZOTTI, 2007).

Outros conceitos se somam aos já mencionados. É o caso do conceito de memória, tomado a CATROGA (2001), que enfatiza, sobretudo, que a memória não é inseparável dos condicionamentos históricos e socioculturais $e_{\text {, }}$ principalmente, da experiência do próprio sujeito que a ela recorre. Para CATROGA (2001), portanto, memória e significação são conceitos inseparáveis. Segundo o mesmo autor, o indivíduo vincula-se no presente a memórias adquiridas, oriundas do passado, e que se projetam para o futuro, abrigando uma rede de vivências plurais e de tempos sociais diferenciados e sobrepostos. Diferentes memórias, portanto, foram consideradas como presentes nos eventos dos festivais e nas canções neles apresentadas, sobrepondo, assim, diferentes significados a eles atribuídos.

\footnotetext{
A memória individual é formada pela coexistência, tensional e nem sempre pacífica, de várias memórias (pessoais, familiares, grupais, regionais, nacionais, etc.) em permanente construção devido à incessante mudança do presente em passado e às consequentes alterações ocorridas no campo das re-presentações do pretérito. Significa isto que a anamnese, enquanto presentepassado, é experiência interior na qual a identidade do eu unifica a complexidade dos tempos sociais em que cada vida individual comparticipa. (CATROGA, 2001, p.16)
}

0 referencial teórico relativo à fenomenologia aplicada à música utilizado nas análises das canções (áudio e vídeo) foi tomado, a diversos autores, dos quais destacamos: CLIFTON (1983), FERRARA (1984), CHAVES (1996), BERGER (1999), SOUZA (2000), DANIELSEN (2006) e FREIRE E CAVAZOTII (2007). Mais especificamente, as análises realizadas utilizam a abordagem que vem sendo desenvolvida por FREIRE (2007), com base, principalmente, no trabalho de CLIFTON (1983). 0 ponto de vista privilegiado, nessa proposta analítica, é o do sujeito (receptor), devendo a análise partir, sempre, da escuta. Assim, a descrição analítica está centrada nas observações do sujeito-receptor, podendo originar diferentes pontos de vista, diferentes concepções e também diferentes conclusões sobre o objeto focalizado.

A performance também foi incluída nas análises, já que se trabalhou com imagens e áudios da época, gravações ao vivo do momento dos festivais. A importância da performance na compreensão de qualquer fenômeno 
é destacada por BERGER (1999), que enfatiza também a importância da experiência, admitindo que há uma relação inevitável entre atividade musical e trama social, sendo todos esses elementos ativados pelo sujeito que os vivencia (BERGER, 1999). Assim, a análise se deu em um horizonte que relaciona memória e história, e que também relaciona o tempo atual (tempo presente, na visão do pesquisador), àquele em que o fenômeno analisado se deu (o momento dos festivais) (BERGER, 1999; DANIELSEN, 2006).

Consideramos, ainda, que a análise musical, procedimento metodológico utilizado na pesquisa, "é um meio precioso para responder a diversas questões de pesquisa devendo, portanto, [...] ser coerente com as questões de pesquisa formuladas" (FREIRE e CAVAZOTTI, 2007, p.35), o que de fato ocorreu, já que as questões da investigação original estão ligadas à inserção social das canções de protesto.

\section{3 - Refletindo sobre as canções}

Buscamos, a partir das bases descritas no item anterior, uma aproximação com as canções selecionadas, abrangendo as relações entre música, letra e ideologia(s) da época, envolvendo também a performance dos artistas e a participação do público dos festivais, sob o entendimento de que esses aspectos não podem ser compreendidos separadamente (BERGER, 1999; DANIELSEN, 2006; FINNEGAN, 2008, entre outros).

A partir da escuta e da leitura interpretativa das canções, realizada nos moldes descritos através da observação de gravações ao vivo em áudio e vídeo, foi realizada uma comparação entre elas, buscando observar possíveis convergências. Essas convergências foram efetivamente percebidas e são resumidamente descritas a seguir. A busca de convergências não representa, contudo, uma tentativa de delimitar padrões generalizáveis, mas de procurar entender algumas formas recorrentes de expressão artística e política.

\section{1 - Tempo e espaço musical, assim como tempo e espaço na narrativa literária, são elementos importantes para a descrição interpretativa das canções}

0 tempo nos pareceu um dos elementos primordiais na caracterização das canções analisadas, revelando convergência entre elas, na forma como se faz presente. Apesar de se apresentar musicalmente como regular e métrico, o tempo foi percebido simultaneamente, na interação com a letra, também como circular, não só pela constante repetição (retorno) de palavras, mas também pela reiteração de elementos melódicos, harmônicos e rítmicos. Essa percepção foi reforçada pelo teor da letra, que sugere, muitas vezes, um "andar em círculos", que não avança ou que não pode avançar, como uma possivel representação das restrições políticas da época, expressas simbolicamente nas estruturas da música e nos versos das canções.
Foi possivel, assim, perceber a sobreposição de diferentes concepções de tempo, das quais destacamos as já citadas no parágrafo anterior: uma concepção de tempo circular e recorrente e uma concepção de tempo linear/ métrico, cuja linearidade nos pareceu ser parcialmente diluída pelo caráter circular sobreposto, característica esta que representa importante convergência entre as canções analisadas.

Outras percepções quanto ao tempo foram vivenciadas como elementos frequentemente presentes nas canções, como uma percepção de não-tempo ou tempo suspenso, bem como de tempos indefinidos e de tempos utópicos. Um sinal fechado, um personagem que para, a fim de ver uma banda passar, alguém que se sente como quem partiu ou morreu são referências que aparecem nas letras e contribuem para uma percepção de suspensão temporal, podendo ser interpretadas como sugestões de desligamento da realidade do momento.

Vários versos das canções apontam para uma suspensão do tempo cronológico: "no peito a saudade cativa, faz força pro tempo parar", em Roda Viva, ou "o homem sério que contava dinheiro parou [...] A namorada que contava as estrelas, parou para ver, ouvir e dar passagem...", em A Banda. Essas alusões literárias a um tempo paralisado ou suspenso se sobrepõem contraditoriamente ao movimento musical linear (percebido a partir da repetição de elementos melódicos, harmônicos, rítmicos), mas consideramos que essas contradições se complementam e se sintetizam no conteúdo expressivo das canções.

Alusões a um tempo futuro, por vezes utópico, aparecem em diferentes versos das quatro canções analisadas, nem sempre de forma explícita, como nos versos "a gente quer ter voz ativa, no nosso destino mandar" (Roda Viva), "tudo bem eu vou indo correndo pegar meu lugar no futuro" (Sinal Fechado). É possível entender que, diante da repressão e da impossibilidade de mudar a realidade naquele momento, o futuro passasse a ser evocado como uma utopia a ser atingida. Nossa percepção, a esse respeito, encontra eco nas observações de VILARINO (1999, p.57): "O sentimento de impotência e a dificuldade de intervir na realidade, não obstante o desejo sincero de fazê-lo, deslocam para o futuro o tempo de atuação, numa mensagem até certo ponto triste, mas que não abandona a esperança".

Em Sinal Fechado, a referência explícita ao tempo ocorre de maneira exaustiva, através de palavras como tempo, futuro, pressa e lembrança, presentes na letra, articulando presente, passado e futuro, memórias (passadas) e expectativas (vindouras). Em Pra não dizer que não falei de flores, percebemos certa prevalência de um tempo projetado para o futuro, como utopia, decorrente de um convite à luta, subjacente à letra ("Vem vamos embora que esperar não é saber / Quem sabe faz a hora não espera acontecer"). Esse tempo utópico, mencionado na letra, se sobrepõe, como já comentado, a um tempo 
musical métrico, que é repetitivo, ciclicamente reiterado pela volta constante de elementos musicais e literários, como, aliás, suscita a forma das canções, geralmente calcadas em estrofes e refrões.

Alusões a um tempo futuro ou utópico, percebidas em nossa análise, revelam, como a literatura revisada também reconhece, referência ao "dia que virá", representando uma esperança em mudanças futuras e acenando com esperança em tempos de desesperança.

Paralelamente, os tempos e espaços (lugares) da narrativa das canções são apresentados pela letra de forma indefinida. Não há uma referência clara ao momento ou ao espaço em que se passam as cenas descritas, que poderiam acontecer em qualquer tempo ou lugar, possivelmente como uma forma de defesa contra a censura. Essas indefinições de tempo e espaço podem ser interpretadas como referências veladas ao momento histórico, parecendo simultaneamente aludir ao anseio por tempos diferentes, sugestão essa que é reiterada pelas referências ao futuro, ao "dia que virá". CÉSAR (2007, p.119), ao analisar alguns aspectos das canções de Chico Buarque, também se refere ao tempo metafórico, o "dia que virá":

\begin{abstract}
Nas canções de protesto [de Chico Buarque], ou melhor, de resistência - pois é assim que o compositor enfrentava a censura -, o tempo assume uma posição de total recusa da situação vigente, fazendo uma proposta de um futuro libertador que assumirá uma função catártica e apocaliptica [...], como elemento transformador e irreversivel, anunciando o futuro libertador do "dia que virá". (CÉSAR, 2007, p.119)
\end{abstract}

Quanto ao espaço musicall, ele se apresenta, preponderantemente, em superfície ${ }^{2}$ de médio a alto relevo (CLIFTON, 1983; DANIELSEN, 2006), abrigando uma linha melódica e uma superfície de fundo, linha essa que por vezes parece mais próxima, por vezes mais distante, mas de qualquer forma envolvente, como cabe ao gênero canção.

0 espaço musical geralmente se amplia nos momentos de clímax das canções, o que certamente estimula o ânimo do público. NAVES (2010) considera esse recurso como consituinte típico de uma "canção de festival", concordando, assim, com nossa percepção de convergência dessa característica entre as canções analisadas. 0 espaço musical é integrado por linhas melódicas que se destacam na voz dos intérpretes, sobre harmonias e ritmos, sobre o "coro" da plateia (público presente ao festival, que canta junto com o artista). Todos esses elementos se integram e se entrecruzam, contituindo o espaço musical preenchido pelas canções, e foram consideradas na análise dos vídeos, revelando um complexo tecido expressivo, de teor político.

Assim, tempo musical e tempo da narrativa, bem como espaço musical e espaço-lugar na narrativa literária, foram percebidos como elementos importantes para uma aproximação interpretativa com as canções selecionadas, permitindo a percepção de algumas semelhanças entre elas, apesar de diferenças de gênero musical, de teor da letra, diversidade de cenas descritas, ou outras.

A sobreposição de tempos, tal como percebida, somada à ambiguidade de espaços/lugares, não impediu o público de se relacionar intensamente com as canções, no momento de suas apresentações nos festivais. 0 público parece reportar-se tacitamente a um entendimento político, comungando significados ocultos veiculados pelas canções, a despeito das performances relativamente contidas dos intérpretes, postura essa certamente herdada da bossanova (a "performance do banquinho e violão inaugurada por João Gilberto", segundo NAVES, 2010, p.29).

\section{2 - Os significados interligam-se às memórias $\mathrm{e}$ às possíveis expectativas que o público traz, sem correspondência necessária com a performance}

A significação dada às canções pelo público, inclusive o entendimento delas como expressões de protesto, parece anteceder ao evento, conforme apontado no item anterior. A reação da plateia parece não decorrer do teor musical ou literário das canções ou da performance dos cantores, cuja apresentação, predominantemente intimista, não parece corresponder às manifestações efusivas do público, mas "a canção termina por existir na experiência de todos" (FINNEGAN, 2008, p.15). Ou seja, o papel das palavras nas canções de protesto, nos festivais, está relacionado ao ambiente de "expectativas específicas de gênero que podem ou não atribuir prioridade particular ao seu sentido referencial ou sua coerência" (FINNEGAN, 2008, p.35).

0 estilo de emissão vocal percebido nas performances das canções selecionadas revela timbres homogêneos, intensidades e ênfases contidas, entre outras similaridades. Todos esses aspectos, à primeira vista, não seriam sinalizadores de protesto ou de qualquer ênfase emocional, mas a reação do público é, de forma aparentemente contraditória, enfática, provavelmente em virtude do emergir de significados construídos anteriormente ao momento específico do festival. "O significado verbal é apenas uma fração do que quer que seja que faz com que músicos e fãs se envolvam e gostem de música popular" (Walser citado por FINNEGAN, 2008, p.33).

Se nos ativermos apenas à música e à letra, sem relacioná-las com 0 momento da performance no festival e desconsiderando as expectativas do público presente, talvez não chegássemos a uma percepção de protesto contido nas canções. Estaríamos, contudo, ignorando a presença de multifacetas do objeto musical, a experiência viva do fenômeno e todos os demais aspectos e processos que o envolvem, bem como a existência de significados subjacentes, alguns recuperados pela memória coletiva do público.

A percepção do público presente, previamente moldada pela condição histórica do momento, faz com que a música se fortaleça como experiência social. Nossa interpretação é, portanto, a de que a memória do 
público que ia aos espetáculos já estava imbuída de significados previamente construídos, configurando uma sobredeterminação social da memória, já que nenhuma experiência se dá no vazio, mas a partir de memórias sociais, coletivas e históricas (CATROGA, 2001). Os significados individuais/coletivos que o público portava complementavam-se nas apresentações ao vivo, numa relação dinâmica de tempos sociais sobrepostos e de vivências plurais que concretizavam, nas apresentações, o caráter de protesto. A análise das gravações de áudio e vídeo é reveladora de rostos emocionados, por vezes tensos, profundamente envolvidos com o que acontece no palco, a despeito de, em algumas imagens, a presença de policiais se fazer nitidamente presente (certamente, não só para garantir a segurança do espetáculo, mas, sobretudo, a do regime político).

\section{3 - Características de continuidade prevalecem nas canções - a inovação é pouco presente}

A inovação não foi percebida, nas análises, como um traço marcante na construção das canções de protesto. Elas pouco ou nada apresentam como elemento inovador, se analisarmos estritamente os elementos musicais ou literários ou se apenas pretendermos reconhecer os gêneros musicais em que se basearam.

Nossa percepção foi a de que um caráter de continuidade prevalece nas canções focalizadas, pela manutenção de elementos de gêneros musicais "tradicionais". Esses elementos conhecidos, contudo, se atualizam no ato dos festivais, ao serem investidos de novos significados, como o caráter de protesto, mesmo não explícito. $\mathrm{Ou}$ seja, a inovação se expressa, nas canções analisadas, sutil e dialeticamente, em simultaneidade com resíduos de concepções anteriores, configurando contradições dialéticas pela presentificação de significados sociais sobrepostos (DANIELSEN, 2006).

É recorrente nas canções de protesto, como já comentado, a utilização de gêneros urbanos, como a marchinha, o samba, a moda de viola, segundo uma visão ideológica que buscava valorizar o "nacional", o "tradicional" de nossa cultura, como reforço de nossa identidade, em um momento que:

\footnotetext{
Promoveu uma atualização do imaginário desenvolvimentista, passando-se a contemplar em nossa cultura não só os aspectos "finos" [...] como também aqueles que se definem pela contaminação entre os diferentes segmentos culturais do país. [...] o conceito de MPB surge [...] não exatamente como decorrência dos impasses criados com o golpe militar, mas sobretudo a partir das reflexões dos compositores sobre a questão da brasilidade. (NAVES, 1999, p.44)
}

A busca de reforçar essa percepção de identidade nacional, presente no ideário de artistas da época, serve-se, assim, da utilização de gêneros populares "tradicionais", de fácil reconhecimento e de fácil assimilação. De acordo com FREIRE (1994), as diversas formas de manifestação artística concretizam conteúdos sociais que se renovam a cada experiência, o que justifica que formas e gêneros "tradicionais" se revistam de novas significações. A forma musical conhecida, de fácil apropriação, aproximava as canções do público, que não só as aprendia com relativa rapidez, mas reconhecia nelas aspectos relativos às memórias plurais e coletivas das culturas brasileiras.

Não era o "grande público", porém, que frequentava os festivais, como revelam claramente as imagens dos vídeos. Por outro lado, os que compareciam não necessitavam das mensagens das canções para serem conscientizados, pois, possivelmente, já detinham informações e entendimentos sobre o momento político que atravessavam. De qualquer forma, estavam profundamente envolvidos com o evento.

Parece, assim, revelar-se um caráter inovador na interação entre letra, música, performance dos intérpretes e participação do público, já que a atualização da experiência de todos, no momento dos festivais, gerava e sobrepunha novos significados. Assim, observamos nas imagens analisadas que o público reage entusiasticamente, cantando ou gesticulando, em momentos em que nem a música, nem a letra e nem a performance do artista parecem suscitar reações mais fortes, o que, provavelmente, corresponde a momentos de evocação e de expressão de memórias sociais e coletivas, canalizados pela canção, que, nesse caso, serve como meio para que essa expressão se concretize. A inovação estaria, assim, nessa nova atribuição de sentidos e significados, ainda que expressa sobre fórmulas musicais e literárias não inovadoras.

\section{4 - Indefinição dos personagens e dos lugares onde se dão as ações}

As referências aos lugares nas canções não são claramente definidas, parecendo apontar para um espaço utópico e irreal, assim como as referências temporais são, também, muitas vezes utópicas, conforme já comentado. Também as descrições das ações dos personagens não aludem a um espaço determinado, permitindo a mesma percepção de tempo indefinido, suspenso e utópico mencionado anteriormente, pois as cenas poderiam se passar em variados lugares. As letras das canções sugerem um espaço "suspenso", inserido em uma dimensão de tempo também suspensa. 0 sinal fechado, da canção que leva esse nome, poderia ser qualquer um, assim, como o lugar onde a banda de Chico Buarque desfila. Quem ia "caminhando e cantando e seguindo a canção", na canção de Geraldo Vandré, poderia ser qualquer um, em qualquer lugar.

Os personagens são citados direta ou indiretamente e não são plenamente definidos, podendo ser reconhecidos como qualquer elemento do "povo". Quem "estava à toa na vida", na canção $A$ Banda, poderia também ser qualquer pessoa, homem ou mulher. Quem "se sente como quem partiu ou morreu", de Roda Viva, também pode ser qualquer um. VILARINO (1999, p.64) apresenta considerações sobre essa mesma canção (Roda Viva), que se aproximam das que nos foram suscitadas pela experiência da análise: 
0 personagem de Chico Buarque é coletivo. Como em outras composições, quando o autor diz "a gente se sente" ou "a gente quer", refere-se a todos que também já sentiram o efeito de estar num dia em que se "partiu ou morreu" [...] Assim, somos nós os personagens, fragmentados, um tanto impotentes [...]. A dor, que, de um lado aflige, mas do outro incita à memória ("no peito a saudade cativa") também é recolhida no movimento dessa rodaviva, pois a saudade é carregada "pra lá". (VILARINO, 1999, p.64)

Por vezes, as canções inserem na cena a presença de um narrador/observador que a relata através da letra e da melodia da canção, cujos contornos, em médio ou alto relevo ${ }^{3}$, sublinham ou reforçam a narrativa. Esse narrador, que geralmente fala na primeira pessoa, favorece a identificação com os personagens da canção, bem como com as situações cotidianas que são narradas (um sinal fechado, uma banda que passa, uma roda de samba que não se realiza, entre outros).

Apesar dessa indefinição de lugares e de personagens, os cidadãos, pelo menos aqueles que compareciam aos festivais, reconheciam as mensagens veladas que esses espaços, tempos e personagens veiculavam, mesmo não sendo explicitados pela letra. Um código silencioso permitia esse reconhecimento, propiciando, assim, nas metáforas e entrelinhas, que as mensagens de descontentamento pudessem se expressar.

\section{5 - Prevalência do papel da linha melódica e da letra}

As linhas melódicas das canções analisadas desempenham, segundo nossa percepção, um papel importante na construção das cenas descritas pelos versos, em total interação com eles. As melodias descrevem traçados geralmente simples, predominantemente sem grandes saltos, mas apresentam certa sinuosidade, com inflexões ascendentes, que finalizam com movimentos por vezes descendentes e, em todos os casos analisados, essa linha se destaca no espaço musical das canções, como, aliás, é característica do gênero.

A subida da linha melódica para acentuar momentos de tensão na letra é um recurso recorrente em canções, não só as dos festivais, bem como a recorrência de desenhos melódicos já ouvidos, reconhecidos pela memória (protensão ${ }^{4}$ ), que têm um papel significativo na interpretação da canção e na recepção dela. Esses recursos contribuem para viabilizar a participação do público, que canta junto com os intérpretes e se emociona frequentemente, o que é visível nas gravações em vídeo analisadas.

As emissões vocais expressam-se, nas gravações observadas, de maneira intimista, sem o uso de recursos enfáticos para sublinhar as possiveis intenções de protesto. Coube à plateia contribuir para os momentos de intensidade na linha vocal, dando vazão à expressão de protesto que as canções não podiam estampar com nitidez, gerando momentos de grande emoção coletiva, como se pode observar na apresentação de Pra não dizer que não falei de flores, de Geraldo Vandré. Após a divulgação do resultado da competição, Vandré tenta, sem sucesso, acalmar o público, insatisfeito com a premiação do festival (0 primeiro lugar neste Festival ficou com a canção Sabiá, de Chico Buarque e Tom Jobim). Por fim desiste e, apesar do grande ruído na plateia, inicia uma introdução ao violão. Depois começa a cantar a canção. As vozes do público vão aos poucos silenciando e se integrando ao cântico, formando, junto com o cantor/compositor, um grande conjunto expressivo, que cresce nos estribilhos. A subida da linha melódica, nesses estribilhos, certamente contribuiu para que esses momentos da canção soassem, nesse grande conjunto, como momentos de clímax e de grande emoção, nesta que é a única canção relativamente explícita como mensagem de protesto político.

Nossa percepção, portanto, deu papel de destaque à linha melódica das canções, e identificou um papel menos importante para a harmonização dessas linhas. A harmonia, segundo nossa interpretação, geralmente não tem um papel tão importante nas canções quanto a letra ou a linha melódica, embora, indubitavelmente, contribua para dar o caráter ou a ambientação à narrativa, complementando, sublinhando ou enriquecendo a linha melódica. De um modo geral, as harmonias são relativamente simples, configurando-se Sinal Fechado como a que apresenta maior complexidade harmônica e melódica, dentre as canções analisadas. Mesmo no caso desta canção (Sinal Fechado), observamos repetições melódicas e harmônicas, pois a harmonia, embora diversificada no interior das estrofes, com acordes alterados, apresenta recorrência de uma estrofe para outra. Ou seja, a ambientação harmônica não traz percepção nova à entrada de nova estrofe, cabendo à letra, nesse caso, garantir a importância da linha melódica na escuta da canção.

De qualquer forma, como no gênero canção a linha melódica é elemento preponderante, o mesmo se observa nas canções analisadas, que despertaram forte adesão do público, como bem revelam as imagens gravadas à época, apesar de não trazerem apelos veementes ou características de inovação musical. A mensagem que elas veiculavam já era esperada, como comentado, assim como a reação emotiva do público presente, provavelmente, já era pré-condicionada.

\section{4 - Considerações finais}

As canções analisadas permitiram revisar alguns aspectos do momento histórico da década de 60, do século $X X$, através de olhares baseados em uma abordagem relativista e diferenciada, que contemplou vídeos e áudio dos momentos ao vivo da realização dos Festivais. Contemplou, também, fontes documentais e depoimentos de época e autores que lançaram seus olhares sobre os festivais e sobre outros movimentos do mesmo período, no Brasil e no mundo, estabelecendo um diálogo com eles. As descrições fenomenológicas e a interpretação relacionada aos conteúdos das épocas abordadas possibilitaram nossa imersão num universo passado, de décadas atrás, permitindo uma leitura interpretativa atual. 
Foi possivel perceber, com base nas observações feitas, algumas convergências entre as canções analisadas quanto a alguns aspectos, bem como perceber uma proximidade entre características do conteúdo musical e literário, da performance e da recepção delas, apesar das diferenças, pois, "mais do que 'a canção' [em si], perguntamo-nos sobre como as pessoas cantam, compõem e escutam, e sobre suas ações e emoções ao fazê-Io" (FINNEGAN, 2008, p.22).

Se as canções de protesto forem ouvidas sem informação prévia sobre o momento político em que foram concebidas, ou mesmo sem a experiência de assistir às gravações ao vivo da época, do momento dos festivais, dificilmente seria atribuído a elas o caráter de protesto com a qual se tornaram conhecidas.

Os festivais de música popular brasileira, realizados na década de 1960, objeto da pesquisa que deu origem a este artigo, enriqueceram nossa música com obras que até hoje são representativas desse período. Além das canções, alguns intérpretes e compositores que ainda estão em voga foram "lançados" nesses festivais. Compositores que alcançaram renome, sendo respeitados nacional e internacionalmente, nos dão exemplos da intensidade artística daquele momento.

Os festivais canalizaram forças artísticas e políticas, aglomeraram indivíduos, ao vivo, no evento, e pela $T V$, ganharam torcidas organizadas, vibrando por determinadas canções. Eles atraíram a atenção de grandes gravadoras e emissoras, que, contudo, contribuíram, segundo alguns autores, para a decadência dos Festivais, quando os interesses comerciais passaram a prevalecer.

Nos espetáculos analisados, tomados como pontos de reflexão, percebemos a música utilizada como portavoz de mensagens de protesto, geralmente veladas, surgidas de compositores ligados à arte universitária e a intelectuais de "esquerda". Nesse âmbito, surgiram as canções analisadas. Elas evidenciam que, principalmente, em momentos dominados por forças coercitivas, manifestações artísticas como essas se dão com objetivos que ultrapassam a mera função de entretenimento, buscando, além de propiciar prazer estético, cumprir um duplo papel de veiculação do protesto e de conscientização dos indivíduos sobre a problemática em questão.

Nossa percepção, segundo as diretrizes metodológicas adotadas, identifica, nos exemplos analisados, características comuns, e, possivelmente, semelhanças com outras canções de protesto daquela época.

A presença de concepções de tempo e de espaço suspensos ou indefinidos, a descrição de cenários imaginários ou utópicos, o desejo de atingir um novo tempo são algumas características que parecem ser compartilhadas pelas canções de protesto, em geral. Na prática, ou seja, no momento da realização dos Festivais, a música interage não só com a letra, mas também com a performance dos intérpretes e a participação da plateia, configurando um momento de expressão política, mesmo que não explícito, no qual estão subjacentes elementos da memória social e, consequentemente, da história da sociedade.

As mensagens veladas nas letras das canções parecem recorrentes, com características musicais que já são familiares ao público, mas, de qualquer forma, atualizamse na nova experiência. As canções analisadas, como já comentado, não apresentam inovações significativas, nem nas letras, nem nos elementos musicais. Ao contrário, predominam recorrências melódicas, harmônicas e rítmicas, que remetem a gêneros musicais e a tempos passados. 0 caráter de inovação, do ponto de vista da construção musical pode, contudo, ser percebido, subjetivamente, diante da experiência atual e atualizante de características pretéritas, na qual as canções são revestidas de novos significados sociais e políticos.

Embora sejam atribuídas, por alguns autores, características conservadoras às canções de protesto e características de inovação ao movimento "Tropicália", que ocorreu nos anos 60 e 70 do século XX, podemos considerar que, de forma peculiar, a inovação também se fez presente nas canções de protesto, reavivando ecos musicais do passado, no momento dos festivais, sob novas significações.

Diferentemente do que se imaginava no início da pesquisa, grande parte da população pode ter continuado indiferente aos acontecimentos, por falta de possibilidade de participação e de informação mais específica, ainda que não se possa afirmar se realmente o intento de todos que se propuseram a compor canções de protesto no período enfocado fosse o de atrair a participação da grande maioria. As trocas parecem ter sido relativamente restritas, uma vez que parte da população talvez nem tenha tomado conhecimento pleno dessas manifestações, ficando à margem do que acontecia. É possível que grande parte da população não tivesse possibilidade de participar do evento ao vivo. A maioria também não possuía aparelho de TV em suas casas, o que também restringe 0 alcance dos festivais, apesar do costume, à época, de assistir à televisão em casa de vizinhos. As canções, entretanto, permitiram trocas diversas entre os indivíduos envolvidos no ato dos Festivais, mas também, ao longo do tempo, pois soaram e estiveram presentes em situações posteriores e trouxeram, para esses momentos, resíduos do passado.

A circularidade cultural pôde ser percebida no retorno ao palco dos festivais de gêneros e de características musicais "esquecidos", oriundos de outros tempos e de outros espaços. A marchinha de $A$ Banda, de Chico Buarque, convertida em canção vencedora do Festival de 1966 (TV Record - SP), certamente trouxe novos aportes ao gênero antigo.

A análise comparativa de canções posteriores ao período 1965-1969 seria interessante para traçar um paralelo 
entre o que foi feito durante a fase inicial dos festivais e o que ocorreu depois, na década de 70, por exemplo, quando os festivais começaram a perder audiência e diminuiu o interesse de compositores, intérpretes, público, entre outros.

Apesar de serem definidos como "festivais da música popular" o que pouco se viu nos eventos ao vivo foi a participação do "povo". Mas quem é o "povo"? Devemos considerar "povo" os que não fazem parte da elite ou "povo" são todos os pertencentes a uma sociedade, sem ênfase em determinadas classes ou segmentos sociais? Observamos, ao analisarmos os vídeos, que o "povo", como parcela da sociedade de menor poder aquisitivo, não aparecia na plateia e, pela pouca disseminação da televisão à época, é possível considerar que relativamente poucos os assistiam pela TV, ainda que não disponhamos de estatísticas a esse respeito. Não abriremos aqui uma discussão mais profunda sobre os conceitos de "povo" e de "música popular", mas as questões apontadas acima parecem efetivamente emergir quando se retorna a reflexão ao tempo dos festivais.

Essas são questões complexas, pois abarcam fatos e concepções igualmente complexos. A música reconhecida, em geral, como "popular" é enormemente variada, de forma que seria possivel ou talvez preferivel abordar 0 conceito no plural, como "músicas populares".
Relembramos que a concepção de tempos múltiplos (FREIRE, 1994) percorreu as análises, estando presente na interação da visão do pesquisador com eventos passados e com autores que, em diferentes épocas abordaram os festivais, bem como no reconhecimento de diferentes concepções de tempo sobrepostas na mesma canção. Para isso, a memória, como elemento articulador, foi importante na interpretação dos dados, pois trouxe para a interpretação sentidos diversos, fazendo interagir dialeticamente diferentes tempos e permitindo reconhecer, nas canções, a presença simbólica desses tempos múltiplos.

Pode-se considerar que a intenção dos compositores e intérpretes das canções era a de "dizer", através de metáforas, o que não podia ser dito, naquele momento, de maneira mais ou menos explícita. Apoiados ou não pela ditadura, hipótese esta que é apresentada por alguns autores, os festivais contribuíram para a eclosão de vários movimentos musicais.

Consideramos, finalmente, que novas pesquisas, com outras abordagens, devem ser realizadas, visando à complementação e enriquecimento deste trabalho, investigando outras canções, abrindo novas questões que possam contribuir para a interpretação do papel da música brasileira na história e atingindo conclusões sempre renovadas.

\section{Referências}

ANDRADE, Carlos Drummond de. Artigo (sem título). Disponível em: <http://www.chicobuarque.com.br/texto/artigos/ mestre.asp?pg=opartigo_drummond.htm>. In: <http://www.chicobuarque.com.br/> Acessado em: 04 out. 2007.

AUGUSTO, Erika Soares. As flores vencendo os canhões: Festivais e Canções de Protesto. 2009. Dissertação (Mestrado em Música). Centro de Letras e Artes, Escola de Música, Universidade Federal do Rio de Janeiro (UFRJ), Rio de Janeiro, 2009.

BERGER, Harris M. Metal, Rock, and Jazz: Perception and the phenomenology of musical experience. United States of America: Wesleyan University Press, 1999.

BURKE, Peter (org.). A escrita da história. São Paulo: USP, 1992.

O que é história cultural? Rio de Janeiro: Jorge Zahar, 2005. Tradução de Sérgio Góes de Paula de "What is cultural history?".

CATROGA, Fernando. Memória, História e Historiografia. 1.ed. Coleção Opúsculos. Coimbra-Portugal: Quarteto Editora, 2001.

CÉSAR, Lígia Vieira. Poesia e política nas canções de Bob Dylan e Chico Buarque. São Paulo: Novera Editora, 2007.

CHAVES, Celso Loureiro. Memórias do passado no presente: a fenomenologia de "Transa". Rio Grande do Sul: UFRGS, 1996.

CLIFTON, Thomas. Music as Heard: A study in applied Phenomenology. New Haven: Yale University Press, 1983.

COUTINHO, Eduardo Granja. Velhas histórias, memórias futuras: o sentido da tradição na obra de Paulinho da Viola. Rio de Janeiro: EdUERJ, 2002.

DANIELSEN, Anne. Presence and Pleasure - The Funk Grooves of James Brown and Parliament. EUA: Wesleyan University Press, Middletown, 2006.

Dicionário Grove de Música: edição concisa. Editado por Stanley Sadie; tradução Eduardo Francisco Alves. Rio de Janeiro: Jorge Zahar Ed., 1994. Tradução de: The Grove concise dictionary of music.

Enciclopédia da Música Popular Brasileira: erudita, folclórica e popular. 2.ed. São Paulo: Art Editora, 1998. ver. Ampl.

FAVARETTO, Celso. Tropicália, alegoria, alegria. 3.ed. São Paulo: Ateliê Editorial, 2000. 
FERRARA, Lawrence. Phenomenology as a Tool for Musical Analysis. In: The Musical Quarterly. New York, 1984. v. 70, n 3, p.355-373.

Richness or Chaos?: Toward a Phenomenology of Musical Interpretation. In: Qualitative Evaluation in the Arts, 1982. 2, p.197-208.

FINNEGAN, Ruth. 0 que vem primeiro: o texto, a música ou a performance?. In: MATOS, Cláudia Neiva de; TRAVASSOS, Elizabeth; MEDEIROS, Fernanda Teixeira (org.). Palavra Cantada: ensaios sobre poesia, música e voz. Rio de Janeiro: 7 Letras, 2008, p.15-43.

FREIRE, Vanda Lima Bellard. A História da Música em Questão: uma reflexão metodológica. Publicado em Fundamentos da Educação Musical, v.2. Porto Alegre: ABEM / 1994.

Música e Pesquisa: novas abordagens. Belo Horizonte: Escola de Música da UFMG, 2007.

GINZBURG, Carlo. O queijo e os vermes: o cotidiano e as ideias de um moleiro perseguido pela inquisição. São Paulo: Cia das Letras, 1987.

HOLANDA, Chico Buarque de. A Banda. Vídeo. Disponivel em: <http://www.youtube.com/watch?v=HEqkkSE3V2E>. Acessado em: 04 out. 2007.

Roda-Viva. Vídeo. Disponível em: <http://www.youtube.com/watch?v=HRFw5u5wR4c>. Acessado em: 31 jan. 2008.

MELLO, Zuza Homem de. A Era dos Festivais: uma parábola. São Paulo: Ed. 34, 2003.

NAVES, Santuza Cambraia. Canção Popular no Brasil. Rio de Janeiro: Civilização Brasileira, 2010.

SOUZA, Luciana Câmara Queiroz de. Tempo e espaço nos Ponteios de M. Camargo Guarnieri: Subsídios para uma caracterização fenomenológica da coleção. 2000. Dissertação (Mestrado em Música). Centro de Letras e Artes, Escola de Música, Universidade Federal do Rio de Janeiro, Rio de Janeiro, 2000.

VANDRÉ, Geraldo. Pra não dizer que não falei de flores (ao vivo). Intérprete: Geraldo Vandré. 1968. In: CD Discoteca Brasileira do Século XX - Anos 60. Faixa: 13. Parceria SESC Rio / SOM. Sistema Globo de Gravações Audiovisuais LTDA. Cedido por Som Livre. Rio de Janeiro: Infoglobo Comunicações S. A., 2007. BR-SGL-68.00014.

VILARINO, Ramon Casas. A MPB em movimento: música, festivais e censura. São Paulo: Olho d'Água, 2006.

VIOLA, Paulinho da. Sinal Fechado. Vídeo. Disponível em: <http://www.youtube.com/watch?v=w9JWuQPeaW0>. Acessado em 31 jan. 2008.

\section{Notas:}

10 espaço musical, segundo CLIFTON (1983), é aquele preenchido pela música, já que ela cria uma área própria, separada dos espaços físicos do mundo, na qual o ouvinte habita enquanto se relaciona com ela, conferindo-Ihe significados de acordo com sua experiência.

2 Superfície é entendida como uma estrutura sem direção clara de sentido, podendo abrigar diferentes elementos, como linhas ou outros, que contribuem mais nitidamente para gerar configurações de sentido (CLIFTON, 1983).

3 Segundo CLIFTON (1983), a superfície de relevo médio ocorre quando uma linha se destaca de uma base relativamente estável, desenhando uma distância média em relação a ela, enquanto na superficie de alto relevo uma linha se projeta mais enfaticamente, ampliando a distância em relação à base.

4 Segundo diversos autores ligados à fenomenologia aplicada à música, protensão refere-se à possibilidade do ouvinte ser capaz de, a partir de uma experiência atual, antecipar uma possibilidade de futuro, de algo que possa vir a ser.

Vanda Bellard Freire é Doutora em Educação Brasileira pela UFRJ, com Pós-Doutoramento realizado na Universidade Nova de Lisboa (Portugal), na área de Musicologia Histórica. Presidiu a Associação Brasileira de Educação Musical, no período 1996/2001. Tem diversas publicações e consultorias realizadas nas áreas de Musicologia e Educação Musical. Tem coordenado projetos de pesquisa e extensão, com apoios CNPq, CAPES, MEC, FUJB e FAPERJ. Foi Conselheira (1997/2006) do Conselho Nacional de Incentivo à Cultura (Ministério da Cultura / Brasil), representando a área de Música. Integra o corpo docente da Escola de Música da Universidade Federal do Rio de Janeiro, onde leciona e orienta trabalhos de pesquisa e extensão em Música, na Graduação e na Pós-Graduação. Está vinculada ao Departamento de Musicologia e Educação Musical.

Erika Soares Augusto é Mestre em Música pela Universidade Federal do Rio de Janeiro (2009) com a pesquisa "As flores vencendo os canhões: Festivais e Canções de Protesto", na área de Musicologia Histórica. Possui Licenciatura em Educação Artística, com habilitação em Música, também pela UFRJ (2004). Foi bolsista do CNPq no período 2002-2004, sob orientação da professora Vanda Freire, tendo obtido o prêmio de melhor trabalho do Centro de Letras e Artes no ano de 2002, na Jornada de Iniciação Científica da UFRJ e, posteriormente, apresentado o referido trabalho na Jornada Nacional de Iniciação Científica e 55a Reunião da Sociedade Brasileira para o Progresso da Ciência, na Universidade Federal de Pernambuco. Atualmente é professora de Educação Musical da Prefeitura da Cidade do Rio de Janeiro. É também professora integrante da Orquestra de Vozes Meninos do Rio, projeto da Secretaria Municipal de Educação do Rio de Janeiro. 